\title{
Editorial
}

\section{Trust-based nursing: Is there a place for trust in nursing science and practice?}

\author{
Lesław T. Niebrój * \\ Medical University of Silesia, School of Health Sciences, Katowice, Poland
}

\begin{abstract}
"In God we trust, all others must bring data." The famous quote attributed to W. Edwards Deming, used by him in the domain of management science, nowadays seems to be welcomed in many, if not every, aspect of our lives [1]. Medicine and in particular biomedical ethics (bioethics) is not an exemption. Reliance on the data, and nothing but the data, has becomes absolutely crucial for modern medicine understood both as a science and as a practice. Reliance on the data, and do not on the people, neither doctors nor nurses... Is there a place for trust in the dataoriented (objectivity-oriented) medicine? Should and could the doctor/nurse-patient relationship be understood and fully explained in the terms of contract between caregiver (provider, vendor) and client (consumer) of health services? Is and should practice of medicine (nursing) remain primarily humanistic rather than strictly scientific endeavor?

Trust has long been considered as fundamental to doctor-patient and nurse-patient relationship [2]. Unfortunately, the concept of trust was associated with medical paternalism which cut off patient's autonomy. Paternalistic approach to medicine was based on health care professionals' (in particular doctors') rather an arrogant but decidedly strong conviction that they know best. Patient's right to the truth was ignored. Paternalistic approach to medical practice accepts that information about diagnosis and prognosis of treatment not only could but, in fact, should be concealed from patients. This, as the consequence, reduces or eliminates patients' ability to make a sound and wise (informed) decisions about their care and cure path. It is perfectly known that today's expectations of the patients would never come to terms with the paternalistic approach to medicine [3].
\end{abstract}

It was really a revolutionary change, when after the ages of the domination of medical paternalism, the respect for patient autonomy became the fundamental (at least in 'praxis' of bioethical discourse) principle of biomedical ethics. The mainstream of bioethics reflections has focused on the issue of patient's informed consent which ultimately (though unintentionally) has led to the assumption of the simplistic view (above-mentioned) that reduces doctor/ nursing-patient relation to the mere contract.

For all those who, though value very high achievements of the contemporary (autonomy-oriented) bioethics, simultaneously are aware that something important was lost in doctor/nurse-patient relationship, careful reflection over the role of trust in medical practice would be the key issue. It is to be emphasized that particularly rich is the reflection over the trust in the discourse in nursing ethics. Just in nursing ethics feminine (rather than feministic) [4] approach to bioethics was and is particularly present. And this feminine view, which always recognized persons as connected, rather than as autonomous and - in certain sense - isolated beings (which is considered to be typical of masculine or justice/contract ethics), seems to create optimal 'climate' for the reflection over the concept of trust.

Such a reflection is needed from both theoretical as well as practical perspectives of nursing [5]. Let me point out the main issues that study on trust in nursing ethics should focused on:

- What trust is not: through every day usage the concept of and the very word "trust" is neither sharp nor unequivocal [6], misunderstanding of the idea of trust

\footnotetext{
* Korespondenční autor: Dr. hab. n. med. Lesław T. Niebrój, Medical University of Silesia, School of Health Sciences, Katowice, Poland; e-mail: lniebroj@wp.pl

http://dx.doi.org/10.1016/j.kontakt.2015.08.005
}

KONTAKT XVII/3: 151-152 • ISSN 1212-4117 (Print) • ISSN 1804-7122 (Online) 
could lead even to the usage of this term in ethically wrong ways (e.g. trust as opposed to rationality, and even as justification of quasi slavery).

- What is the specificity of trust based on: in particular in the relation to the concepts which seems to be close to the concept of trust, for instance reliability (trusting can be betrayed, reliance "only" disappointed) [7].

- Is the ethics of trust opposed to the ethics of justice/ contract (feminine/based on love vs masculine/based on obligation ethics) or rather complementary each other (ethics is human, i.e. feminine and masculine).

- What are essential components of trust: integrity (but what is integrity (?) pure predictability, or predictability of morally good action), competence, good will, respect etc.

- Is that true that self-trust is crucial: "Mistrusting their own moral integrity may turn professionals from moral actors into victims of circumstances" [8].

- What about the role of trust for effectiveness of the whole therapeutic team, protection against burn-out syndrome but also if/in how degree individual nurse is responsible for social trust to the whole profession $\mathrm{s} /$ he represented?

- And last but not least (somebody would probably say it is central issue): how trust-based relationship between nurse-patient influences on the course and effects of treatment?
When responding to the all the above posed questions I strongly advise to assume the perspective of a trustee rather than a trustor. Or in other words: who I am as a trustee? Summing-up, let me propose the conception of Trust-Based Nursing (TBN), which might turn out much more influential that Evidence-Based Nursing (EBN).

\section{REFERENCES}

[1] Lynch J, Stuckler D. 'In God we trust, all others (must) bring data.' Int J Epidemiol 2012;41(6):1503-6; doi: 10.1093/ije/dys204

[2] Niebrój L. Bioetyka programów życiowych. Rozwinięcie koncepcji pryncypializmu Beauchampa i Childressa. Katowice: SUM; 2010.

[3] Bártlová S, Tóthová V, Brabcová I, Prokešová R, Kimmer D. The hospitalized patient as a partner in the survey on safe care in the Czech Republic. Neuro Endocrinol Lett 2014;35(Suppl. 1):5-10.

[4] Peter E, Morgan KP. Exploration of a trust approach for nursing ethics. Nurs Inq 2001;8:3-10.

[5] Manhas KP, Mitchell I. (Dis)-Trust in transitioning ventilator-dependent children from hospital to homecare. Nurs Ethics 2014; doi: 10.1177/0969733014551598.

[6] Thominet P. Ethique et relation de confiance. Soins 2013;58(779):28-9.

[7] McLeod C. Trust. In: The Stanford Encyclopedia of Philosophy; 2014. [online] [cit. 2015-07-31]. Available from: http://plato.stanford.edu/archives/sum2014/ entries/trust/

[8] Gronlund CE, Soderberg AI, Zingmark KM, Sandlund SM, Dahlqvist V. Ethically difficult situation in hemodialysis care - Nurses' narratives. Nurs Ethics 2014; doi: 10.1177/0969733014542677. 